\title{
Assessment of bioclimatic sensitive spatial planning in a Turkish city, Eskisehir
}

\author{
Süleyman TOY ${ }^{1 *}$, Savaş ÇAĞLAK ${ }^{2}$ and Aslıhan ESRINGÜ³ \\ ${ }^{1}$ Department of City and Regional Planning, Faculty of Architecture and Design, Atatürk University, 25254 Yakutiye/ \\ Erzurum, Turkey. \\ ${ }^{2}$ Graduate School of Social Sciences, Department of Geography, Mayls University, 55270 Atakum/Samsun, Turkey. \\ ${ }^{3}$ Department of Landscape Architecture, Faculty of Architecture and Design, Atatürk University, 25254 Yakutiye/ \\ Erzurum, Turkey. \\ *Corresponding author; email: suleyman.toy@atauni.edu.tr
}

Received: August 14, 2020; accepted: March 4, 2021

\begin{abstract}
RESUMEN
La ciudad de Eskişehir está ubicada en la región de Anatolia central, Turquía, donde prevalecen rigurosas condiciones climáticas continentales (i.e., inviernos fríos y veranos calientes). En años recientes, la calidad y cantidad de los estudios relativos a confort bioclimático han aumentado, tanto globalmente como en Turquía. Las condiciones externas de confort bioclimático se encuentran entre los indicadores de calidad de vida en ambientes urbanos, junto con otras características físicas, sociales y económicas como la calidad del aire, el PIB y la posibilidad de realizar actividades sociales. Los valores que representan condiciones de confort bioclimático se han utilizado en lugar de los valores medios individuales de algunos elementos climáticos para establecer el grado de habitabilidad de una ciudad. El objetivo del presente estudio es determinar: 1) condiciones horarias de confort bioclimático en el centro de la ciudad de Eskişehir en días de calor sofocante, tomando en cuenta valores de confort bioclimático, calculados a partir de una base de datos de 12 años de zonas rurales, urbanas y suburbanas, con un índice de temperatura fisiológica equivalente y el software RayMan para determinar los flujos de radiación solar en individuos durante los cinco meses más calurosos del año; 2) la distribución espacial de estos valores en intervalos de 10 días utilizando sistemas de información geográfica y mapas de bits, tomando en cuenta la elevación y los usos del suelo; y 3) qué diseño urbano y principios de planificación pueden adoptarse para enfrentar condiciones de confort climático adversas desencadenadas por el efecto de la isla urbana de calor. Los resultados del estudio indican que las peores condiciones de confort corresponden a áreas urbanas y las mejores a zonas rurales. Se toman en cuenta nuevos principios de diseño urbano sensibles a aspectos bioclimáticos para crear áreas más confortables desde la perspectiva bioclimática (es decir, sitios con más viento y menos humedad, en los que se aproveche la dirección prevalente del viento y se evite el estrés por exceso de calor).
\end{abstract}

\section{ABSTRACT}

The city of Eskişehir is located in the Central Anatolia Region of Turkey, where harsh continental climatic characteristics are prevalent (i.e., cold winters and hot summers). In recent years, quality and quantity of studies on bioclimatic comfort have increased both all over the world and in Turkey. Outdoor bioclimatic comfort conditions are counted amongst the indicators of human quality of life in urban environments, together with other physical, social and economic features such as air quality, GDP, and possibilities of social activities. The calculated values representing bioclimatic comfort conditions have been used instead of individual mean values of some climatic elements, in order to provide an insight of the liveability of a city. The aim of the present research study is to determine: (1) hourly bioclimatic comfort conditions in the Eskişehir city center during sultry summer days, considering bioclimatic comfort values calculated according to 12 -year data from 
urban, sub-urban and rural areas using the physiological equivalent temperature (PET) index and RayMan software for the calculation of solar radiation fluxes on individuals in the hottest five months of the year; (2) the spatial distribution of these comfort values in decades (10-day intervals) using Geographic Information Systems and raster maps, taking into consideration elevation and land use; and (3) which urban design and planning principles could be adopted to deal with adverse thermal comfort conditions triggered by the urban heat island (UHI) effect. The results of the study indicate that the poorest comfort conditions are provided in urban areas, while rural areas are more advantageous in terms of comfort conditions. New bioclimatic-sensitive urban design principles are taken into consideration to create more comfortable areas from the bioclimatic perspective (i.e., windier and less humid sites open to the prevalent wind direction and out of heat stress).

Keywords: Bioclimatic comfort, urban climate, spatial planning principles, PET, RayMan, Eskişehir.

\section{Introduction}

Prevailing climatic conditions at a certain point on the Earth shape anthropological activities, including all socioeconomic, cultural, architectural and manufacturing activities, as well as mental and psychological wellbeing. Humans live in convenience with climatic conditions by adjusting all their habits to them and establishing settlements where suitable climatic conditions are prevalent. Following the Industrial Revolution, the sudden migration of population masses to the newly and distorted developing, unhealthy industrial cities caused rapid deteriorations and disorders in every aspect of human life, including economic, social, legal and urban development. Depending on the spatial expansion of cities, natural areas were transformed into structured areas dominated by buildings, and asphalt and concrete surfaces. Such changes, together with other air polluting anthropogenic factors like industrial manufacturing, corrupted the environmental conditions of cities by differentiating climate characteristics. A paradigmatic example is the first industrial city, London, where the first urban-rural climatic differences appeared, as explained by Luke Howard in his book The climate of London published in 1820 (apud. Landsberg, 1981). Although ancient people are reported to have perceived different characteristics of urban climate as understood from the descriptions of Vitruvius (75-26 BC) in Roman times (Fukuoka, 1997), there has been a growing interest in urban climatology studies since the beginning of the 20th century (Landsberg, 1981).

The ISO standard 7730 (ISO, 2005) defines thermal comfort as the state of mind that expresses satisfaction with the surrounding environment. Uncomfortable atmospheric conditions for humans such as prevalent extreme temperatures (heat/cold waves) may cause serious or even fatal health problems (chronic disorders, fatigue, headaches, mortality, etc.), decreases in work efficiency, and mental and psychological crises (Nastos and Matzarakis, 2011; Błażejczyk et al., 2018; Aboubakri et al., 2020). The concept bioclimatic comfort refers to optimum climatic conditions in which people are not warned against climate elements and feel comfortable (Toy, 2010). It can be stated that situations in which the human nervous system is not stimulated to balance body temperature, are accepted to be the conditions in which people are not thermally disturbed, that is, comfortable (Höppe, 1999; Laschewski and Jendritzky, 2002).

As reported in several previous studies (Unger, 1999; Robaa, 2003; Toy and Yılmaz, 2010; Çalışkan and Türkoğlu, 2014; Demircan and Toy, 2019), both bioclimatic comfort features and climatic conditions show differences between urbanized areas and their rural counterparts depending on some physical factors like city size (Oke, 1973), population and topography. Therefore, bioclimatic comfort conditions need to be investigated considering not only climatic elements but also the thermal characteristics of human body such as workload, clothing, psychological factors, etc.

Urban areas produce climatic changes due to their modified surface characteristics compared to rural and semi-rural areas. As the urban surfaces embrace varying artificial structures like buildings, asphalt-concrete roads, roofs, green areas and other elements, they reflect different thermal properties. Such characteristics also determine the general urban microclimate. Therefore, urban climates show differences between cities depending on their urban morphology (e.g., urban canyon, green infrastructure). 
In the literature, urban thermal comfort conditions are evaluated generally associated with urban heat islands (UHIs) and their intensity from various parts of the world (Unger [1999] in Hungary; Robaa [2003] in Egypt; Demircan and Toy [2019] in Turkey, etc.). Such results are in similar ranges with those found in previous studies, e.g., in the hot and continental climate city of Szeged, Hungary, where the difference in the urban-rural physiological equivalent temperature (PET) index was found to be $2.9{ }^{\circ} \mathrm{C}$ (Gulyas et al., 2010). In the same country, Hungary, in the city of Budapest, the mean yearly PET difference between urban and rural settings was determined to be $3.0^{\circ} \mathrm{C}$ (Kovacs and Nemeth, 2012). Blazejczyk et al. (2016) found a $4-5{ }^{\circ} \mathrm{C}$ mean difference in the Universal Thermal Climate Index (UTCI) in Warsaw, Poland, between a densely built city part and an area covered with low-density buildings and higher vegetation. In a study in Turkey, the mean urban-rural PET difference in the city of Ankara was $2.2{ }^{\circ} \mathrm{C}$ during the summer (Çalışkan and Türkoğlu, 2014). In Şanlıurfa, one of the hottest cities in Turkey, the yearly mean PET difference was found to be $2.1^{\circ} \mathrm{C}$ between urban and rural areas (Toy et al., 2018). Toy and Yilmaz (2010) found urban-rural comfortable range differences for the thermohygrometric index (THI) and the predicted mean vote (PMV) of 2.2 and $0.7 \%$, respectively, in a small sized and unindustrialized city, Erzincan, Turkey,.

In urban environments, surfaces with increased heat storage capacity have adverse effects on human bioclimatic comfort conditions, recreation possibilities and human well-being by causing heat stress on individuals, especially during summer (Balik and Yüksel, 2014). However, recreational activities to be performed in livable urban environments with favorable bioclimatic comfort conditions have social, psychological and economic advantages in developing countries like Turkey (Toy and Yilmaz, 2009).

Tools that use spatial weather data in urban environment and that can assist decision makers in developing plans and strategies to minimize the negative impacts of urbanization on human thermal comfort have been developed and used to produce several useful products like maps for urban climate, thermal comfort conditions, air pollution, modeling and simulation maps (e.g., Envi-Met [Bruse, 2004] and RayMan [Matzarakis et al., 2007]). Spatial urban meteorological data obtained from real-time monitoring systems or modeled data based on the mentioned tools can help determine the spatial distribution of unfavorable conditions related to urban climate from a bioclimatic perspective, such as uncomfortable zones and areas prone to the UHI. Results of studies that use these methods and tools help authorities in planning the correct measures to cope with them (Y1lmaz, 2013; Paramita and Matzarakis, 2019).

Cities, especially in developing countries like Turkey, face a rapid and deteriorating urbanization process in which natural land surfaces are turned into impervious ones. This undesired process produces urban areas with weak livability due to unfavorable and uncomfortable bioclimatic conditions. As mentioned above, all bioclimatic planning and modeling in urban environments have valuable results regarding more livable cities. As a developing country, Turkey has experienced a long-lasting urbanization process since the beginning of heavy industrialization attempts in the 1950s centered in large cities. This growth caused rural migration to urban settings as in other countries. The study area of this article, Eskişehir, started its industrialization and urbanization process in the 1930s, earlier than other Turkish cities. Public investments in Eskişehir aimed to develop manufacturing and railway industries (Gümüş, 2004), which in turn produced a rapid, unplanned and distorted urbanization process (Toy et al., 2019).

In the scope of this study, the bioclimatic comfort conditions of Eskişehir's city center are analyzed considering the warm period of the year (from May to the end of September) in order to determine the comfortable and uncomfortable zones and periods using PET, a widely accepted thermal comfort index (VDI, 1998; Höppe, 1999; Matzarakis et al., 1999), and the RayMan calculation model (Matzarakis et al., 2007). The obtained PET values were mapped with the software package ArcGIS10.1 to show areas reflecting unfavorable bioclimatic comfort conditions, which allows to intervene and determine measures from the urban planning and geographical perspectives.

\section{Materials and methods}

The study area is the city of Eskişehir, located on a plain (760-800 masl) in the Upper Sakarya subregion 
of Central Anatolia, Turkey ( $39^{\circ} 49^{\prime}-39^{\circ} 43^{\prime} \mathrm{N}, 30^{\circ}$ $24^{\prime}-30^{\circ} 43^{\prime}$ E). The city is surrounded by the Sündiken mountains and high plateaus to the north. It is divided by the Porsuk stream, a branch of Sakarya river flowing from north to the south (Fig. 1).

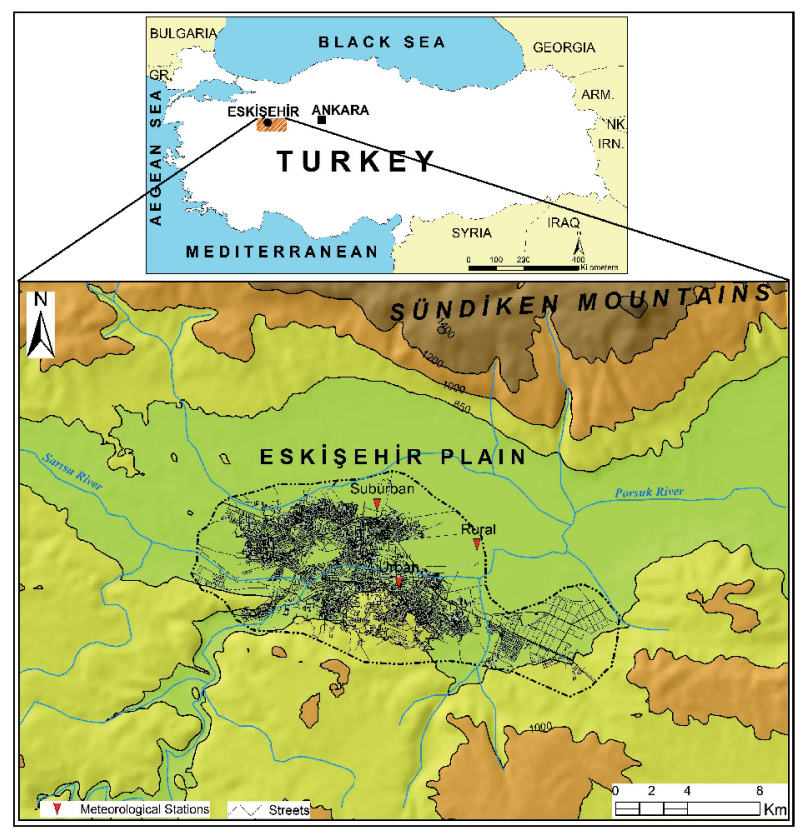

Fig. 1. Location of the study area.

The city center is comprised of two central districts (neighborhoods), Tepebaşı and Odunpazarı. Several industrial facilities, such as sugar, aircraft and automotive factories, as well as universities, are established in the city center. Since Eskişehir is located in an important road network junction, it has experienced a rapid industrialization and has received significant migration from its surroundings.

Continental climatic characteristics are prevalent in the city, with hot summers and dry, cold, snowy winters. The annual average temperature is $10.6^{\circ} \mathrm{C}$ (with extreme minimum of $27.8^{\circ} \mathrm{C}$ in January and extreme maximum of $40.6{ }^{\circ} \mathrm{C}$ in July). Annual rainfall is $307.2 \mathrm{~mm}$ and relative humidity is $65 \%$. The average annual wind speed is $3.1 \mathrm{~m} \mathrm{~s}^{-1}$ and the prevalent wind direction is SW (Table I).

Hourly and daily meteorological data were obtained over a 12-year observation period (2007-2018) to precisely evaluate bioclimatic comfort values, from three meteorology stations located in (1) the Eskişehir Regional Meteorology Administration, representing a densely structured urban area (U), (2) Anadolu University campus, representing a suburban area (SU), and (3) Eskişehir airport, representing an open rural area (R). Table II presents the features of the meteorological measurement stations.

Twelve-years hourly data of 153 days, covering the summer period, were used in this study. Meteorological data used were air temperature $\left(\mathrm{Ta}\left[{ }^{\circ} \mathrm{C}\right]\right)$, relative humidity $(\mathrm{RH}[\%])$, wind velocity (Wv $[\mathrm{m} / \mathrm{s}]$ ), and cloudiness (octas; $\mathrm{x} 10^{-1}$ ).

In this study, the worldwide PET index (VDI, 1998; Höppe, 1999; Matzarakis et al., 1999) and the RayMan radiation model (Matzarakis et al., 2007), were used to calculate bioclimatic comfort values. PET considers not only the combined effects of climatic parameters on individuals but also factors related directly to human body, like physical activity, clothes and physical features like age, weight and length as coefficients. In this respect, human bioclimatic comfort conditions were calculated considering coefficients according to a 35 year-old man with a height of $175 \mathrm{~cm}$ and a weight of $75 \mathrm{~kg}$ under a clothing insulation of 0.9 clo and activity load of 80 W (Matzarakis and Mayer, 1996; Matzarakis et al., 1999).

Bioclimatic comfort intervals given in Table III were used in order to divide the calculated PET values into categories according to the predetermined thermal sensation and stress levels. Distribution of the calculated hourly PET values was determined considering nine ranges from very cold through comfortable to very hot in all temporal and spatial analyses in the area.

Spatial distribution of the calculated hourly PET values was dtermined using the 10-day averages and categories mentioned above with ArcGIS 10.1 software. Elevation data and land use characteristics (e.g., open green spaces, impervious surfaces, roofs which show different radiation properties) of the study area were included in the spatial analysis in the software. PET, elevation and land use data were overlapped in raster form. Points where data representing U, SU and R surface characteristics were obtained. U represents densely structured neighborhoods with 5-6 story buildings, while SU is a university campus 
Table I. Long-term means of some climatic parameters (1975-2018).

\begin{tabular}{|c|c|c|c|c|c|c|c|c|c|c|c|c|c|}
\hline Eskişehir & Jan & Feb & Mar & Apr & May & June & July & Aug & Sep & Oct & Nov & Dec & Mean \\
\hline $\begin{array}{l}\text { Mean } \\
\text { temperature }\left({ }^{\circ} \mathrm{C}\right)\end{array}$ & 0.5 & 0.7 & 4.6 & 9.7 & 14.7 & 18.9 & 21.8 & 21.5 & 16.7 & 11.7 & 5.7 & 1.4 & 10.6 \\
\hline $\begin{array}{l}\text { Mean maximum } \\
\text { temperature }\left({ }^{\circ} \mathrm{C}\right)\end{array}$ & 3.7 & 6.0 & 11.3 & 16.6 & 21.8 & 26.0 & 29.1 & 29.2 & 25.0 & 19.8 & 12.4 & 5.5 & 17.2 \\
\hline $\begin{array}{l}\text { Mean minimum } \\
\text { temperature }\left({ }^{\circ} \mathrm{C}\right)\end{array}$ & -4.2 & -4.0 & -1.4 & 2.9 & 6.9 & 10.4 & 13.1 & 13.1 & 8.4 & 4.6 & 0.2 & -2.2 & 4.0 \\
\hline $\begin{array}{l}\text { Mean sunshine } \\
\text { duration }(\mathrm{h})\end{array}$ & 2.4 & 3.5 & 5.2 & 6.2 & 8.4 & 10.2 & 11.1 & 10.4 & 8.4 & 6.1 & 4.2 & 2.1 & 6.4 \\
\hline $\begin{array}{l}\text { Mean number of } \\
\text { rainy days }\end{array}$ & 11.6 & 11.6 & 11.2 & 11.3 & 9.5 & 6.0 & 3.8 & 3.3 & 4.4 & 8.1 & 9.3 & 12.4 & 8.5 \\
\hline $\begin{array}{l}\text { Mean monthly } \\
\text { rainfall }\left(\mathrm{kg} \mathrm{m}^{-2}\right)\end{array}$ & 27.9 & 23.5 & 26.1 & 42.0 & 37.4 & 20.7 & 13.4 & 9.4 & 16.3 & 26.8 & 29.6 & 34.1 & $\begin{array}{l}307.2 \\
\text { (Total) }\end{array}$ \\
\hline $\begin{array}{l}\text { Extremely high } \\
\text { temperature }\left({ }^{\circ} \mathrm{C}\right)\end{array}$ & 18.2 & 20.5 & 28.1 & 30.8 & 33.3 & 36.4 & 40.6 & 39 & 36.4 & 33.0 & 25.4 & 21.4 & 30.3 \\
\hline $\begin{array}{l}\text { Extremely low } \\
\text { temperature }\left({ }^{\circ} \mathrm{C}\right)\end{array}$ & -27.8 & $-22 . .4$ & -12.0 & -10.4 & -2.2 & 0.5 & 5.0 & 5.4 & -2.0 & -6.8 & -12.2 & -19.2 & -8.7 \\
\hline $\begin{array}{l}\text { Mean wind } \\
\text { speed }\left(\mathrm{m} \mathrm{s}^{-1}\right)\end{array}$ & 3.0 & 3.2 & 3.3 & 3.1 & 3.3 & 3.7 & 3.4 & 2.8 & 2.4 & 2.7 & 2.7 & 3.1 & 3.1 \\
\hline $\begin{array}{l}\text { Prevalent wind } \\
\text { direction }\end{array}$ & WSW & $\mathrm{S}$ & WSW & SW & NNW & WNW & W & NW & W & W & ESE & SW & SW \\
\hline $\begin{array}{l}\text { Mean relative } \\
\text { humidity }(\%)\end{array}$ & 77 & 73 & 66 & 63 & 62 & 57 & 53 & 55 & 60 & 66 & 71 & 78 & 65.0 \\
\hline
\end{tabular}

Source: Turkish State Meteorological Service.

Table II. Meteorological stations used in this study.

\begin{tabular}{cccl}
\hline $\begin{array}{c}\text { Represented } \\
\text { area }\end{array}$ & Location & $\begin{array}{c}\text { Altitude } \\
\text { (masl) }\end{array}$ & Surface \\
\hline $\mathrm{U}$ & $39^{\circ} 45^{\prime} 56.2^{\prime \prime} \mathrm{E}, 30^{\circ} 33^{\prime} 00.7^{\prime \prime} \mathrm{N}$ & 801 & Densely structured \\
$\mathrm{SU}$ & $39^{\circ} 48^{\prime} 29.9^{\prime \prime} \mathrm{E}, 30^{\circ} 31^{\prime} 55.2^{\prime \prime} \mathrm{N}$ & 786 & Loosely structured \\
$\mathrm{R}$ & $39^{\circ} 46^{\prime} 51.6^{\prime \prime} \mathrm{E}, 30^{\circ} 34^{\prime} 46.9^{\prime \prime} \mathrm{N}$ & 787 & Not structured \\
\hline
\end{tabular}

in loosely structured open space and $\mathrm{R}$ is an airport base with very few buildings near the measurement point (Fig. 2).

\section{Results}

Distribution of hourly and daily mean, maximum, minimum and extreme PET values during the whole study period (153 days) according to time of the day and areas (i.e., U, SU and R) is given in Table IV and Figure 3. It can be seen from the table that 12year mean PET values are $21.0^{\circ} \mathrm{C}\left(35.0\right.$ to $\left.10.6^{\circ} \mathrm{C}\right)$, $19.6{ }^{\circ} \mathrm{C}\left(32.4\right.$ to $\left.9.0^{\circ} \mathrm{C}\right)$ and $18.6^{\circ} \mathrm{C}\left(32.0\right.$ to $\left.7.3^{\circ} \mathrm{C}\right)$ in $\mathrm{U}, \mathrm{SU}$ and $\mathrm{R}$, respectively. There is a 1.4, 2.4 and $1.0^{\circ} \mathrm{C}$ mean PET difference between $U$ and SU, U and $\mathrm{R}$, and SU and R, respectively. Mean maximum PET 
Table III. Human thermal sensation and stress ranges of PET (Matzarakis et al. 1999; Höppe, 1999).

\begin{tabular}{|c|c|c|}
\hline $\begin{array}{l}\text { PET } \\
\left({ }^{\circ} \mathrm{C}\right)\end{array}$ & Thermal sensation & $\begin{array}{l}\text { Level of thermal } \\
\text { stress }\end{array}$ \\
\hline$<4$ & Very cold & Extreme cold stress \\
\hline $4.1-8$ & Cold & Strong cold stress \\
\hline $8.1-13$ & Cool & Moderate cold stress \\
\hline $13.1-18$ & Slightly cool & Slight cold stress \\
\hline $18.1-23$ & Neutral (comfortable) & No thermal stress \\
\hline $23.1-29$ & Slightly warm & Slight heat stress \\
\hline $29.1-35$ & Warm & Moderate heat stress \\
\hline $35.1-41$ & Hot & Strong heat stress \\
\hline$>41$ & Very hot & Extreme heat stress \\
\hline
\end{tabular}

PET: physiological equivalent temperature.
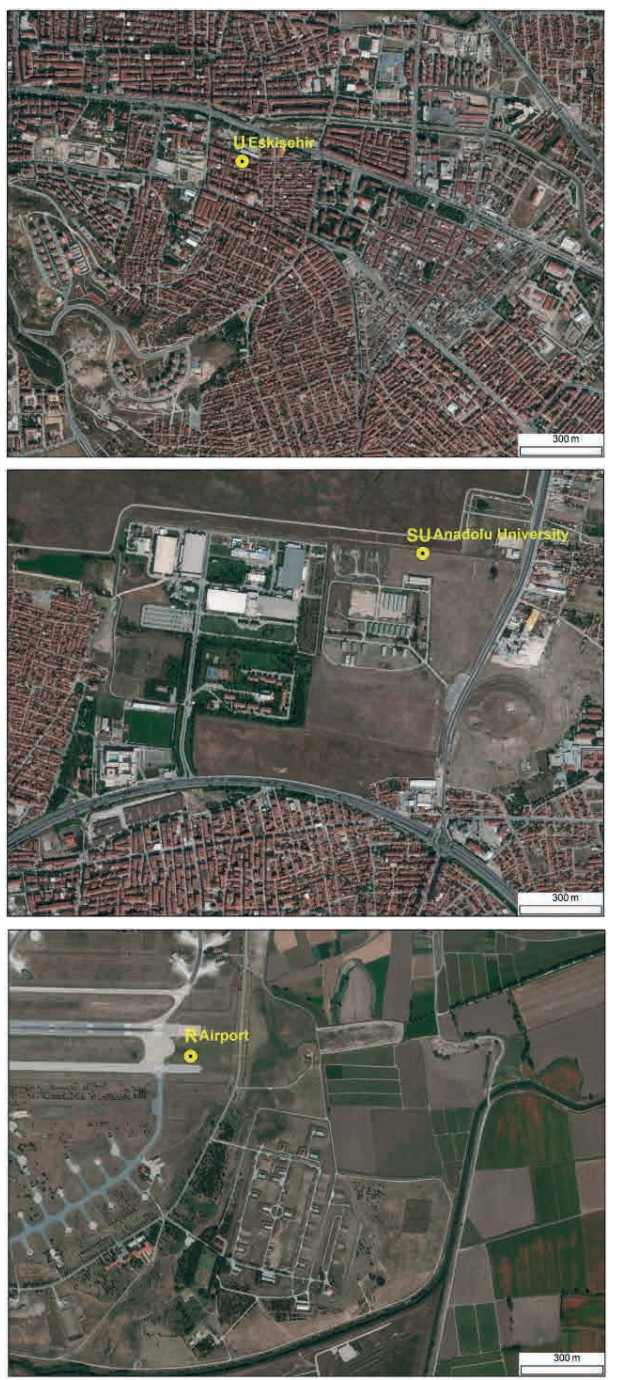

Fig. 2. Surface characteristics of the measurement points.

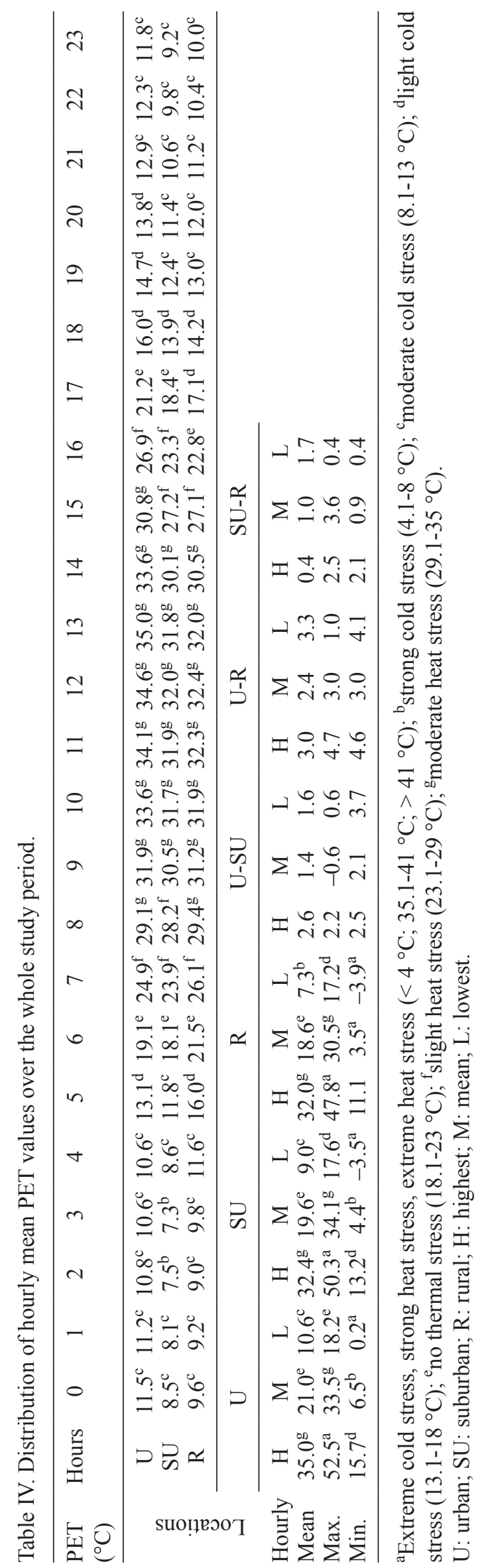




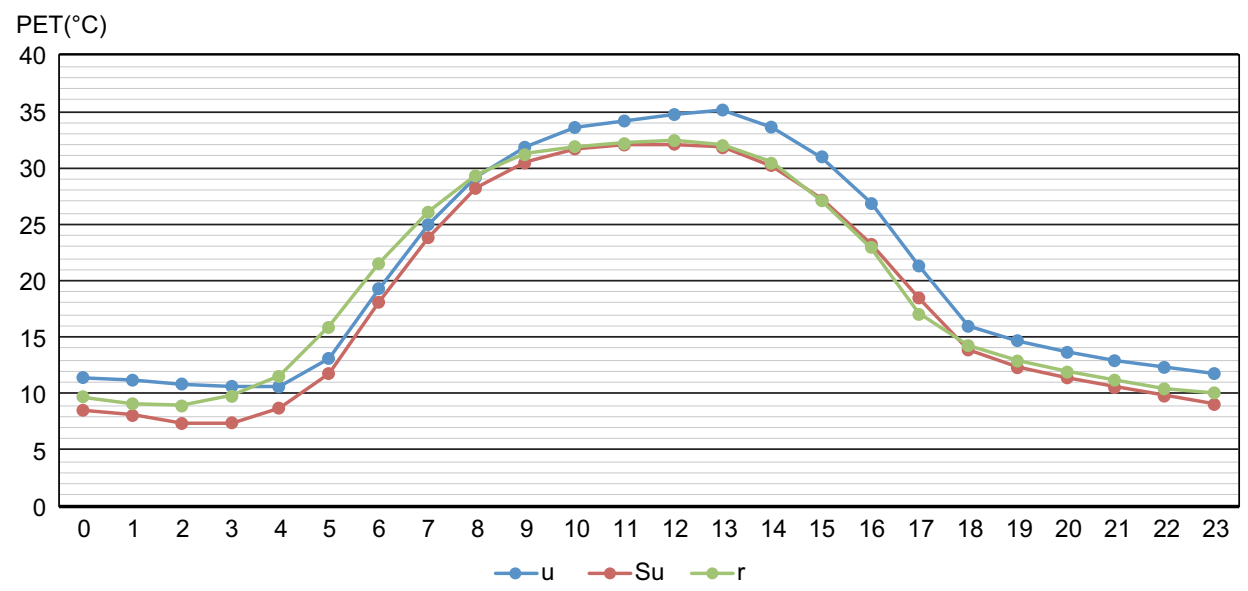

Fig. 3. Hourly trend of PET values throughout the day.

values are $33.5^{\circ} \mathrm{C}\left(52.5\right.$ to $\left.18.2{ }^{\circ} \mathrm{C}\right) 34.1{ }^{\circ} \mathrm{C}$ (50.3 to $\left.17.6{ }^{\circ} \mathrm{C}\right)$ and $30.5^{\circ} \mathrm{C}\left(47.8\right.$ to $\left.17.2^{\circ} \mathrm{C}\right)$, while mean minimum PET values are $6.5^{\circ} \mathrm{C}\left(15.7\right.$ to $\left.0.2{ }^{\circ} \mathrm{C}\right)$, $4.4{ }^{\circ} \mathrm{C}\left(13.2\right.$ to $\left.-3.5^{\circ} \mathrm{C}\right)$ and $3.5^{\circ} \mathrm{C}\left(11.1\right.$ to $\left.-3.9^{\circ} \mathrm{C}\right)$ in $\mathrm{U}, \mathrm{SU}$ and $\mathrm{R}$, respectively, over the whole study period. There is a $-0.6,3.0$ and $3.6^{\circ} \mathrm{C}$ maximum PET difference and a 2.1, 3.0 and $0.9^{\circ} \mathrm{C}$ minimum PET difference between $\mathrm{U}$ and $\mathrm{SU}, \mathrm{U}$ and R, and SU and $\mathrm{R}$, respectively.

In all areas, the comfortable time interval is $1 \mathrm{~h}$ in the morning at 6.00 LT and $1 \mathrm{~h}$ in the evening at 17:00 LT in $\mathrm{U}$ and $\mathrm{SU}$, and at 16:00 LT in R. Moderate and slight cold stress is prevalent from 18:00 LT (17.00 LT in rural areas ) to $5.00 \mathrm{LT}$. $\mathrm{R}$ is less exposed to heat stress ( $1 \mathrm{~h}$ less than other areas). The largest heat stress is seen in $U$, but the severity of heat stress is $2 \mathrm{~h}$ less in SU than U.

The largest difference in mean PET values is seen between $U$ and $R$, as expected. Between areas, differences in mean PET values are smaller than those in the averages of maximum and minimum PET values. In terms of maximum PET values, SU represents warmer characteristics than $\mathrm{U}$; however, in mean and minimum PET values $U$ is the warmest area, which is consistent with the results of previous studies.

It is clearly understood from Figure 3 that $\mathrm{U}$ shows the highest PET values during the early morning (09:00-03:00 LT), as R shows a rapid temperature increase after sunrise, while SU reflects a similar trend in the afternoon.

Table V shows the hourly distribution of comfort ranges throughout the day in the evaluated period.
It is seen that the area where the largest number of comfortable hours is seen is U with $431 \mathrm{~h}$ (of $3672 \mathrm{~h}$ in the hot period; $11.7 \%$ ), the smallest number of comfortable hours is seen in $\mathrm{R}$ with $356 \mathrm{~h}(9.7 \%)$, while comfortable hours in SU amount to $10.8 \%$. U has $0.9 \%$ more comfortable hours than SU and $2 \%$ more than R, while SU has 1.1\% more comfortable hours than $\mathrm{R}$ (TableV).

Figure 4 shows the hourly distribution of PET values in $U$ over the whole study period. It is seen that cold and cool ranges (cold stress) are perceived from 19:00 to 04:00 LT $(10 \mathrm{~h})$ and between 09:00 and 16:00 LT ( $8 \mathrm{~h}$ ) warm and hot ranges (heat stress) are dominant. The comfortable range spans only between 05:00 and 08:00 LT and 17:00 and 18:00 LT (6 h).

Figure 5 shows the hourly distribution of PET values in the SU over the whole study period. Cool and cold ranges (cold stress) are dominant between 19:00 and 05:00 LT (11 h), while warm and hot ranges (heat stress) are seen between 10:00 and 15:00 LT (6 h) and comfortable conditions prevail between 06:00 and 09:00 and 16:00 and 18:00 LT (7 h).

Figure 6 shows the hourly distribution of PET values in the rural area throughout the study period. Cool and cold ranges (cold stress) are seen between 18:00 and 04:00 LT (11 h) while warm and hot ranges (heat stress) are seen between 10:00 and 14:00 LT (4 h) and comfortable conditions are prevalent between 05:00 and 10:00 and 15:00 and 17:00 LT (9 h). Daily PET values were mapped at 10-day intervals to detect their spatial distribution in the city center according to the stations. It can be seen in this figure that slightly 
Table V. Distribution of comfort ranges in hours and percentage.

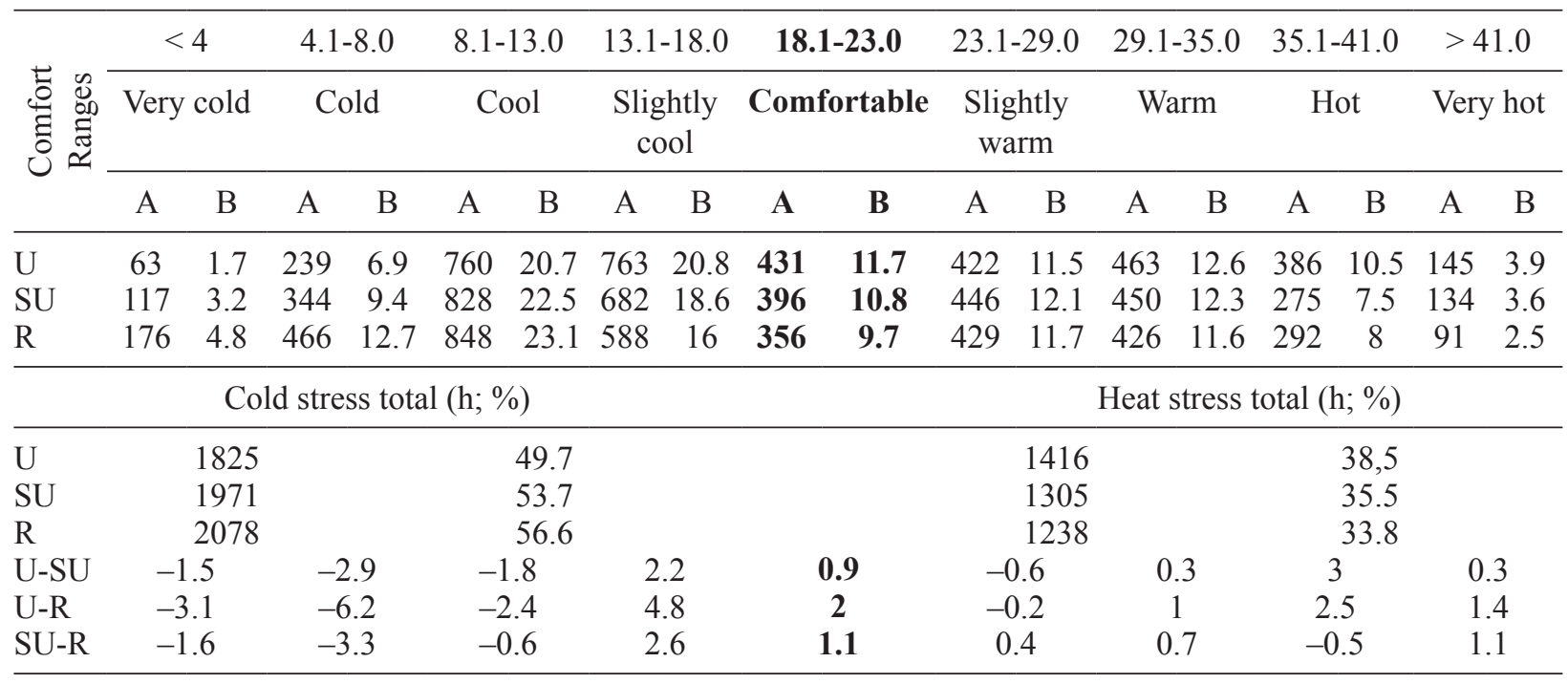

A: total hours; B: percentage of hours.

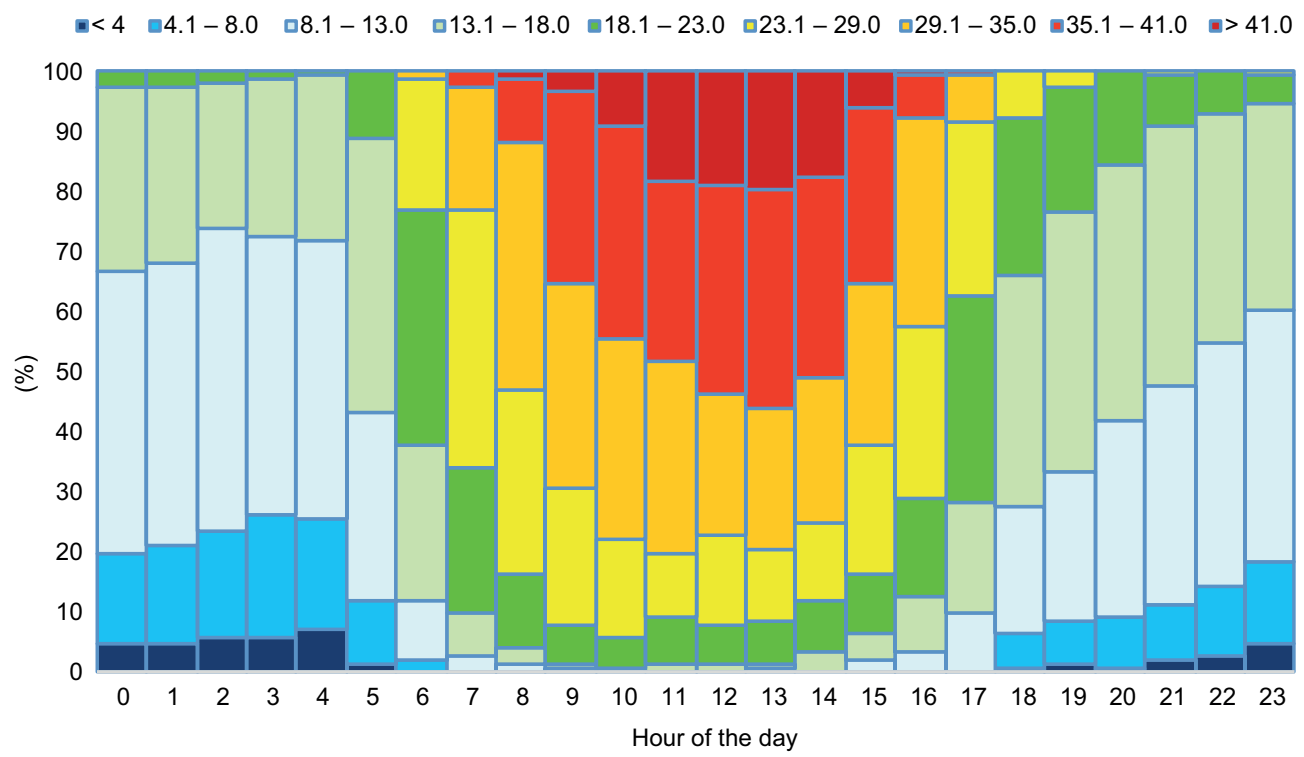

Fig. 4. Hourly distribution of PET values in U over the study period.

cool conditions are perceived in the whole study area when the spatial distribution of average daily PET values from day 130 to 150 day are considered. On day $160,55.8 \%$ of the study area is in comfortable range, $44.2 \%$ is under the effect of slightly cool conditions, comfortable conditions are observed in the urban area. On day $170,11.3 \%$ of the study area is in comfortable range and $88.7 \%$ is under the effect of slightly cool range. Comfortable conditions are determined to be prevalent in the areas covered by dense buildings and narrow streets in the city. This is because in the first and last months of the study period during nighttime and some hours of daytime, air temperature is lower in suburban and rural areas 


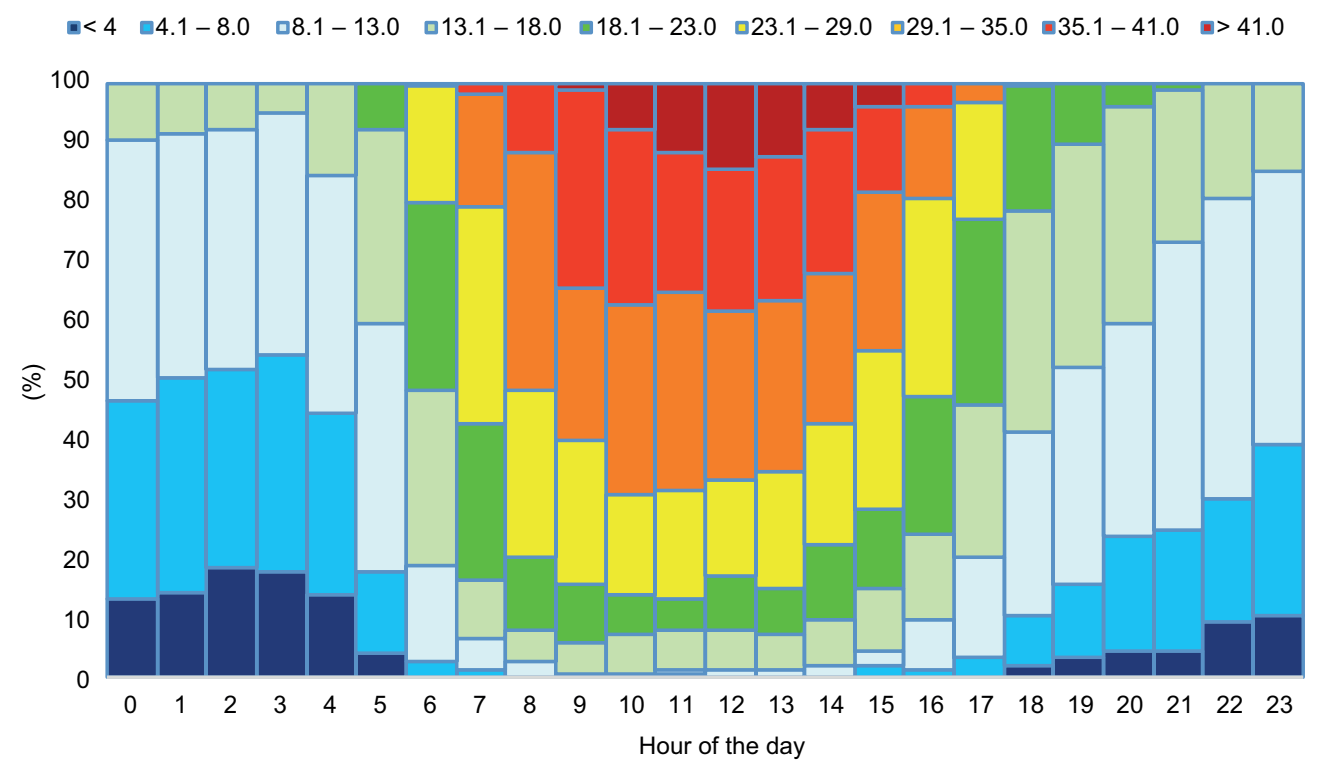

Fig. 5. Hourly distribution of PET values in SU over the study period.

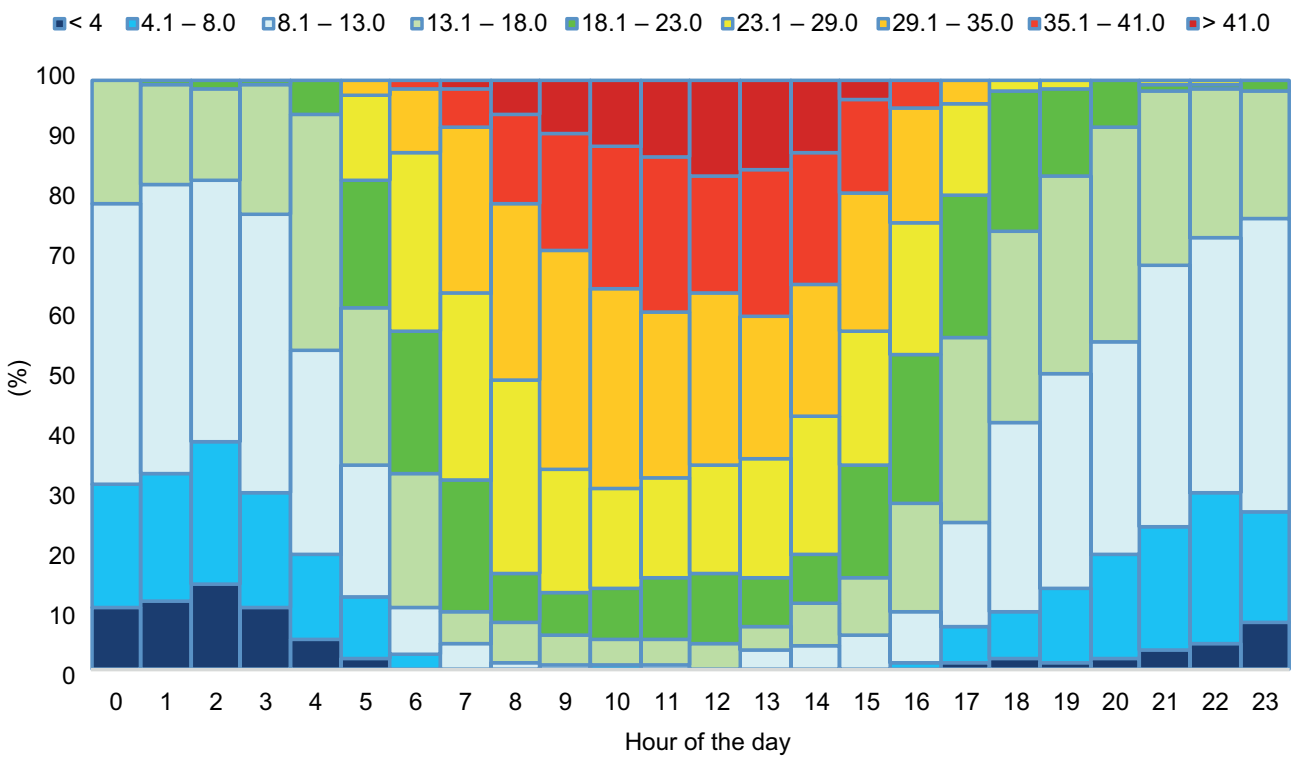

Fig. 6. Hourly distribution of PET values in R over the study period.

but higher in urban areas due to the UHI effect, which causes longer hours of calculated comfortable range. On the day 180, while slightly warm conditions (heat stress) are seen in densely built urban areas $(3.5 \%)$, comfortable conditions are prevalent in the vast majority of the area $(96.5 \%)$. Slightly warm conditions were determined in urban areas $(32.8 \%$ of the whole study area) on day 190. Comfortable conditions were determined in $67.2 \%$ of the study area, covering rural and suburban areas. On day 200, a slightly warm stress was determined in the majority of urban and suburban areas and $(60.6 \%$ of the study area). Comfortable conditions were perceived in rural areas and (39.4\% of the study area). On days 210 and 220 , a slightly warm stress was detected in the whole area. On day 230, a slightly warm stress was observed 
in the urban area, which accounts for $57.6 \%$ of the whole area. Comfortable conditions were experienced in the remaining $42.4 \%$ of the study area, corresponding to rural environments. On day 240, comfortable conditions were perceived throughout the whole area and on day 250 comfortable conditions were observed in urban and suburban areas. Comfortable conditions were detected in $61.7 \%$ of the area on day 250, while a slight cool stress was detected in the remaining $38.3 \%$ (rural settings). On day 260, a slight warm stress was experienced in the urban area $(24.5 \%$ of the whole study area). Comfortable conditions were observed in $75.5 \%$ of the study area (suburban and rural). While the urban and suburban areas were comfortable on day 270, a slight cool stress was determined in the rural area (Fig. 7).
Figure 8 exhibits the spatial distribution of mean daily maximum PET values. It is seen that slightly warm stress was experienced across the study area on day 130 while comfortable conditions were prevalent in $70.9 \%$ of the area and slight warm stress in the rest. While a slightly warm stress was observed in the urban area, comfortable conditions were found in suburban and rural areas. It can be inferred from this result that due to the effect of urban morphology and surface, the urban area gets warmer earlier than the rest and remains calmer (less windy), which reflects on bioclimatic comfort values. On day 150, a slightly warm range is prevalent in the whole area, while a warm range is prevalent on day 160 . On day $170,62.2 \%$ of the area experienced warm stress and $37.8 \%$ was under the effect of slightly warm stress. On day 170 , warm

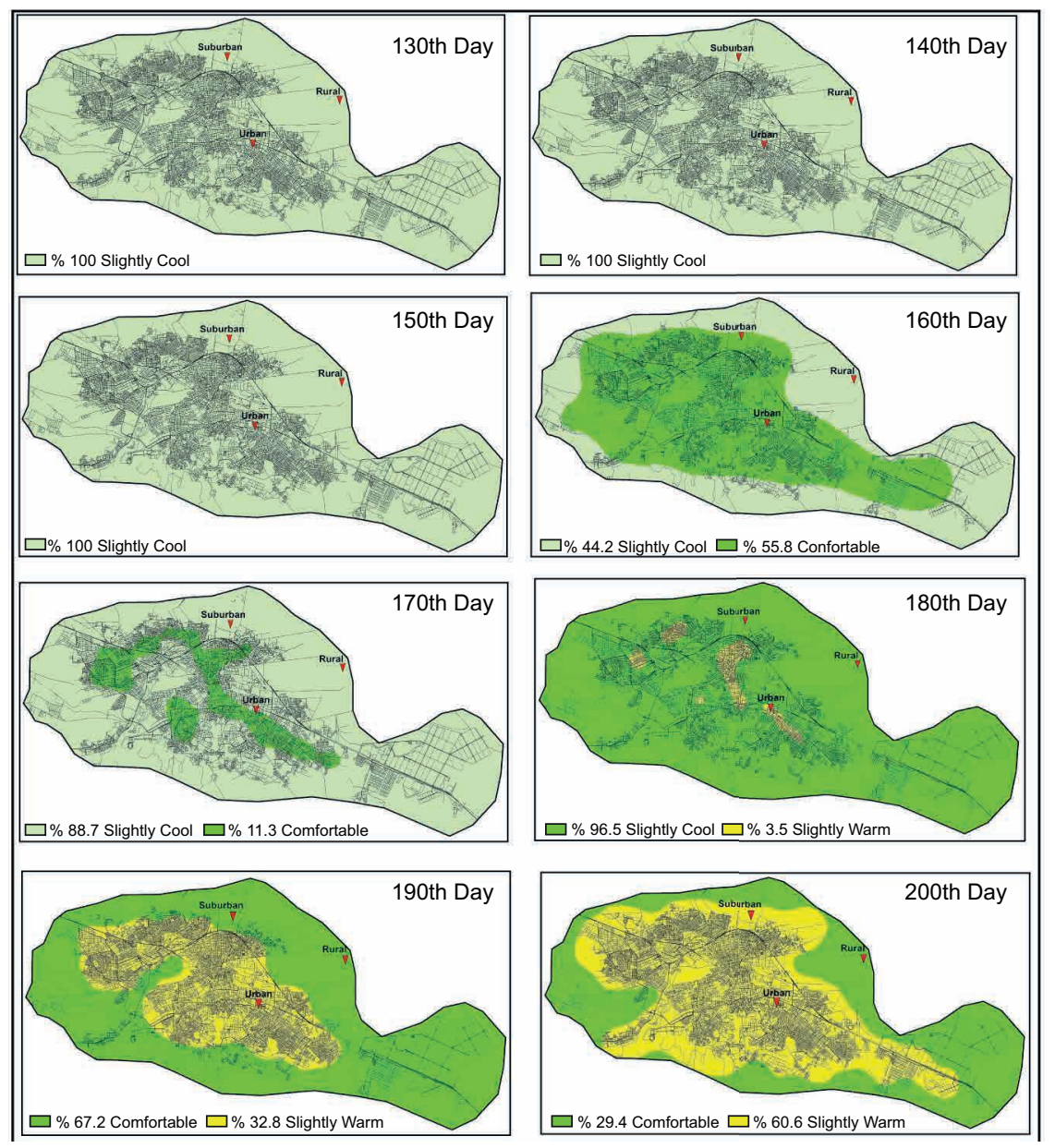

Fig. 7. Spatial distribution of daily mean PET values. 


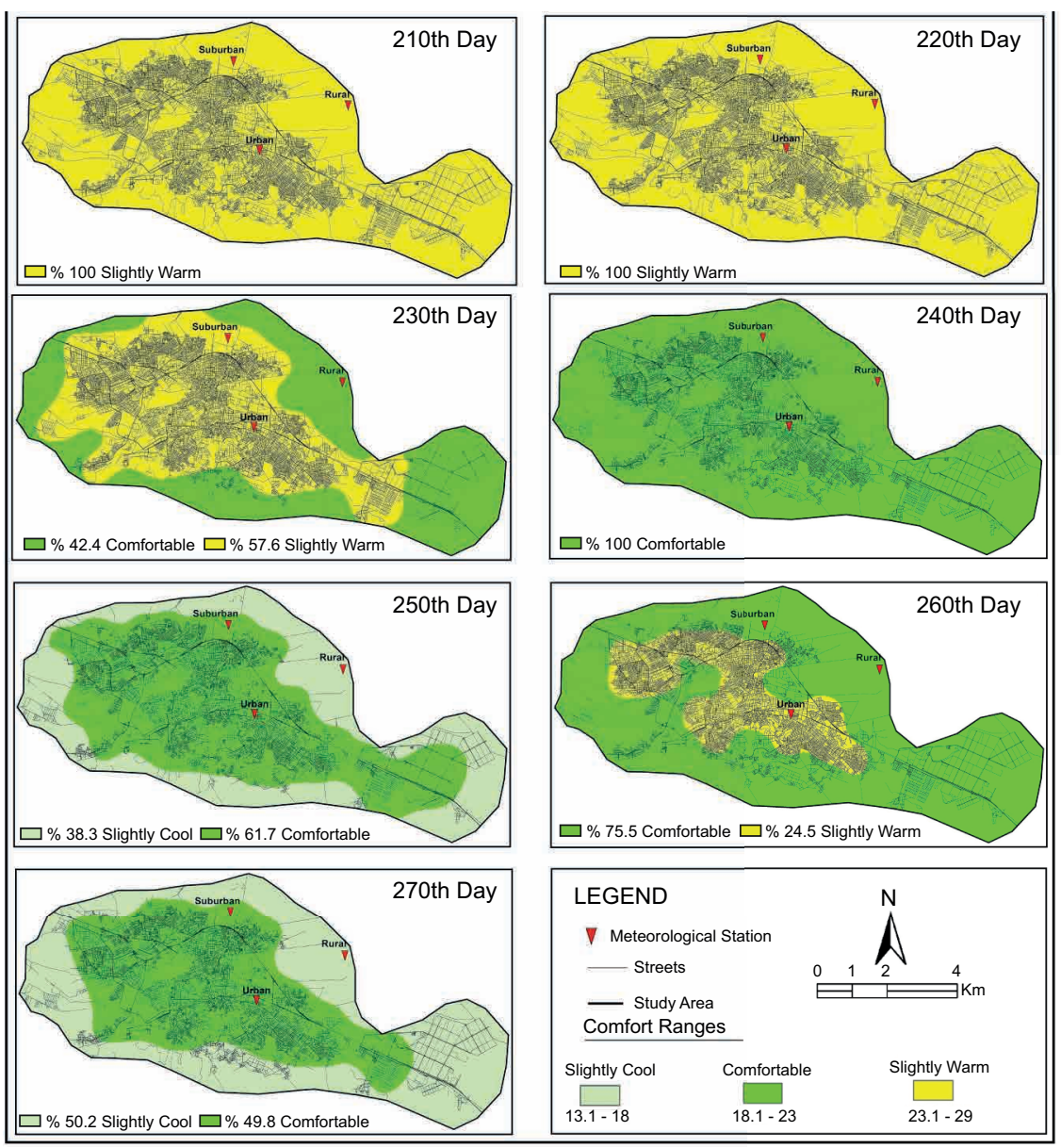

Fig. 7. Spatial distribution of daily mean PET values.

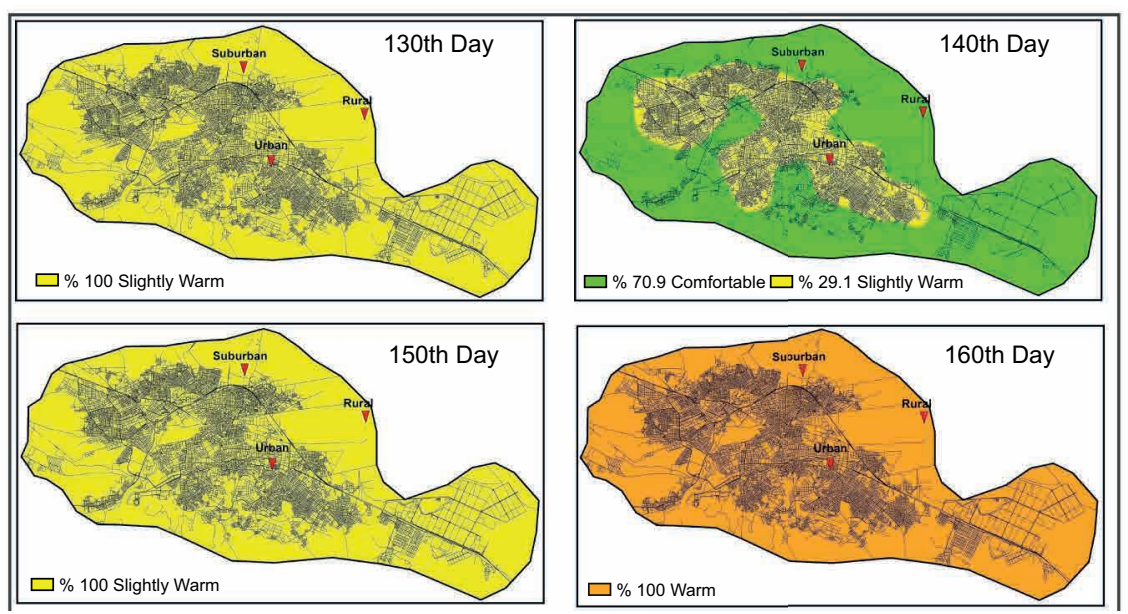

Fig. 8. Spatial distribution of daily mean maximum PET values. 


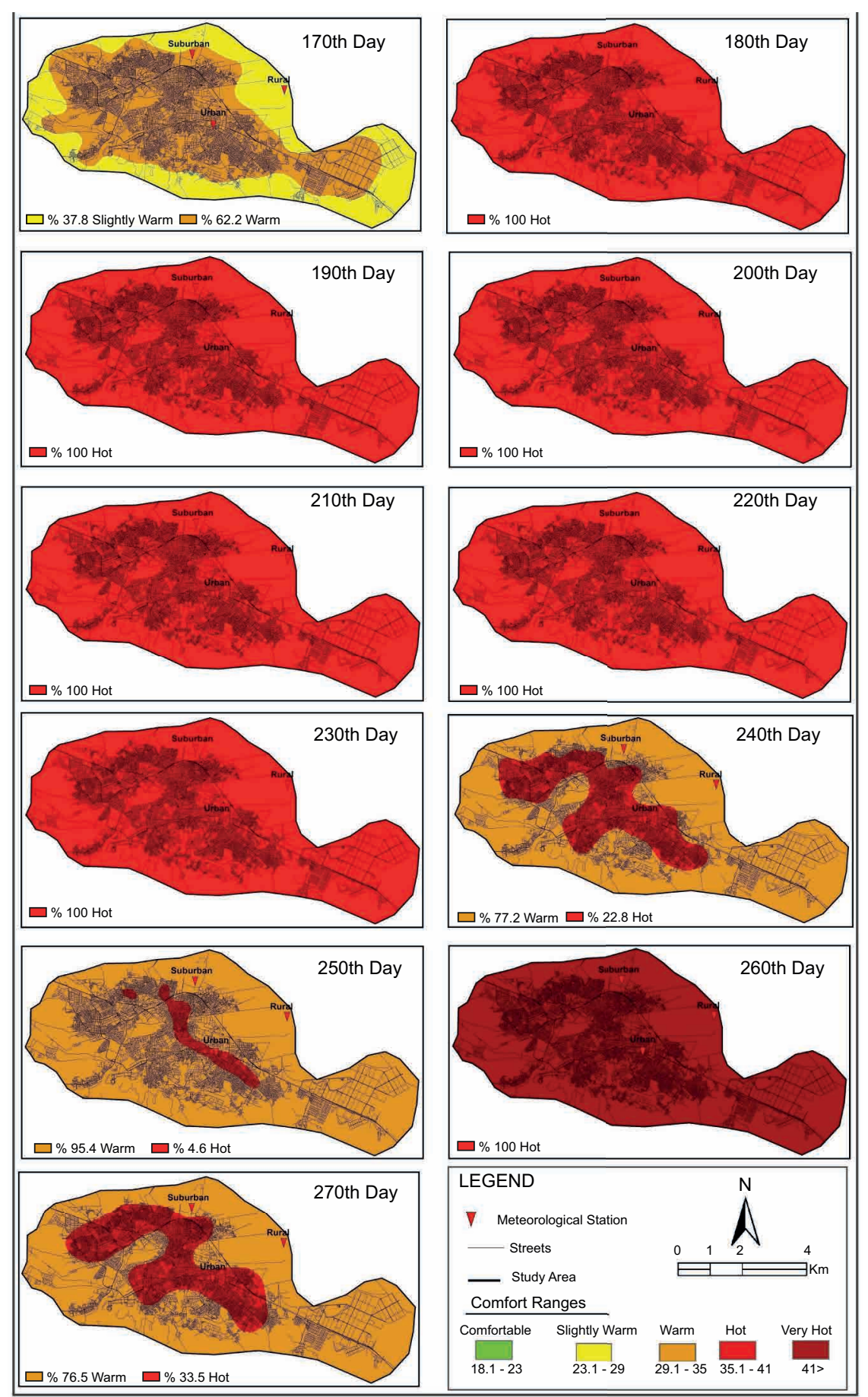

Fig. 8. Spatial distribution of daily mean maximum PET values.

stress was observed in urban and suburban areas, while slightly warm stress was observed in the rural area. From day 180 to 230, hot stress was observed throughout the study area. On day 240, 22.8\% of the area consisting of dense urban areas experienced hot stress. In areas covering rural and suburban areas $(77.2 \%)$, a warm stress was observed. On day 250, warm stress was determined in $95.4 \%$ of the area, and hot stress in 
dense built areas (4.6\%). On day 260, heat stress was experienced in the whole area. On day $270,33.5 \%$ of the area revealed hot stress and $76.5 \%$ warm stress. Hot stress was determined in densely built areas and warm stress in suburban and rural areas. PET values calculated for urban, suburban and rural areas fell into different comfort ranges on days 160, 170, 180, 190, 200, 230, 250, 260 and 270. The density of the built surface (ratio of empty spaces), urban texture (type and height of buildings and orientation and width of streets) and the characteristics of surface covers are expected to be the effective features on the spatial differences of PET values. Compared to rural areas, urban PET values fall into the next warmer comfort range on all days mentioned above while PET values for suburban are sometimes in the same range than urban and rural.
As stated by Grimmond (2007), this condition of urban areas is related to their larger surface due to 3-D geometry of buildings, causing greater rate of solar radiation absorption, higher heat storage capacity of surface materials, smaller rate of heat loss through air movement (canyon geometry), larger impervious surface areas, lower evapotranspiration, and higher additional energy supply from combustion of fossil fuels and electricity.

Figure 9 shows the spatial distribution of mean daily minimum PET values. It is seen that on day 130 , the rural area $(48.1 \%$ of the study area) was under very cold stress, urban and suburban areas (50.7\%) were under cold stress, and a portion of the urban area $(1.2 \%)$ was under the effect of a cool range. On day $140,43.1 \%$ of the area was under the effect of very

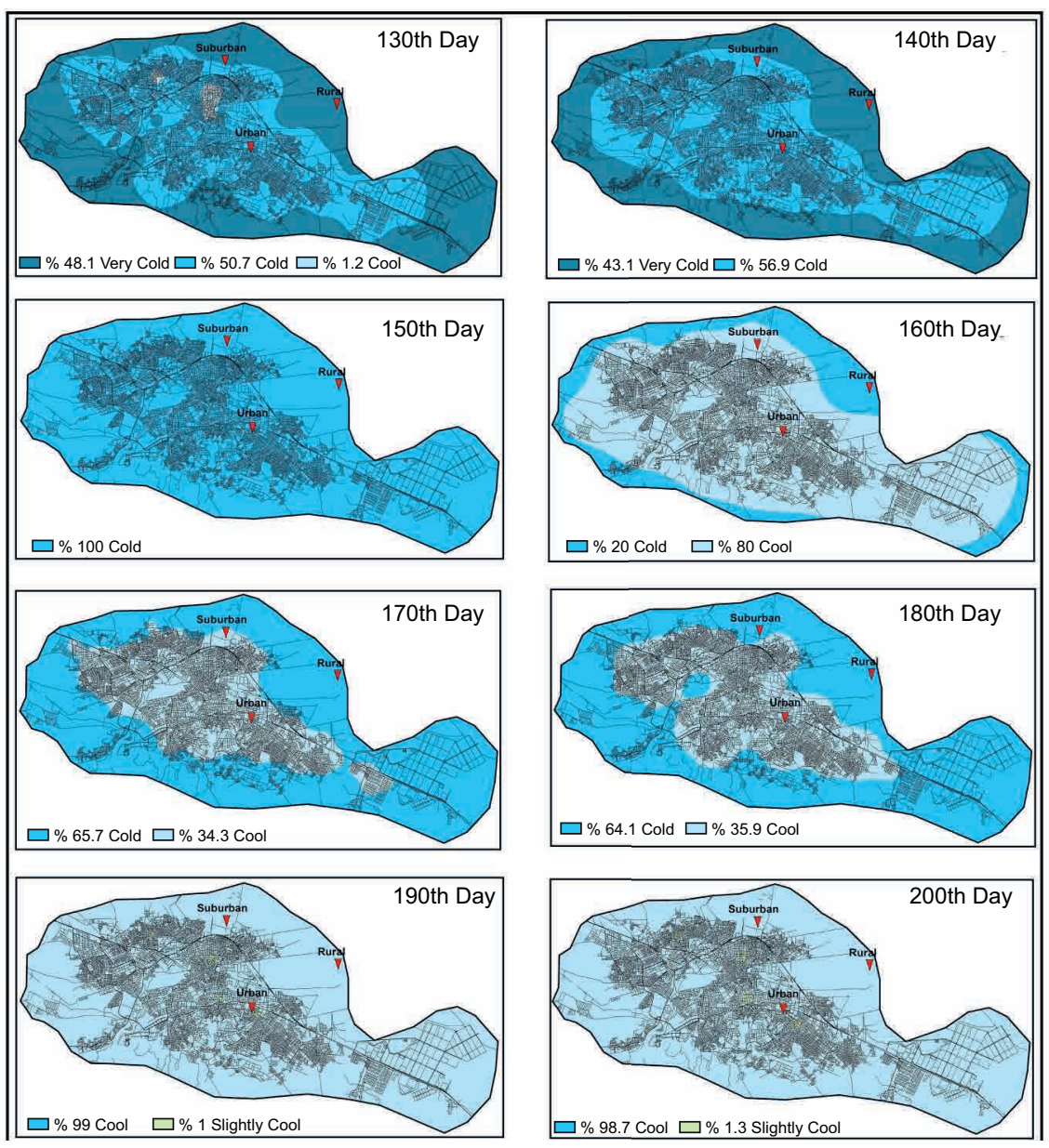

Fig. 9. Spatial distribution of daily average minimum PET values. 


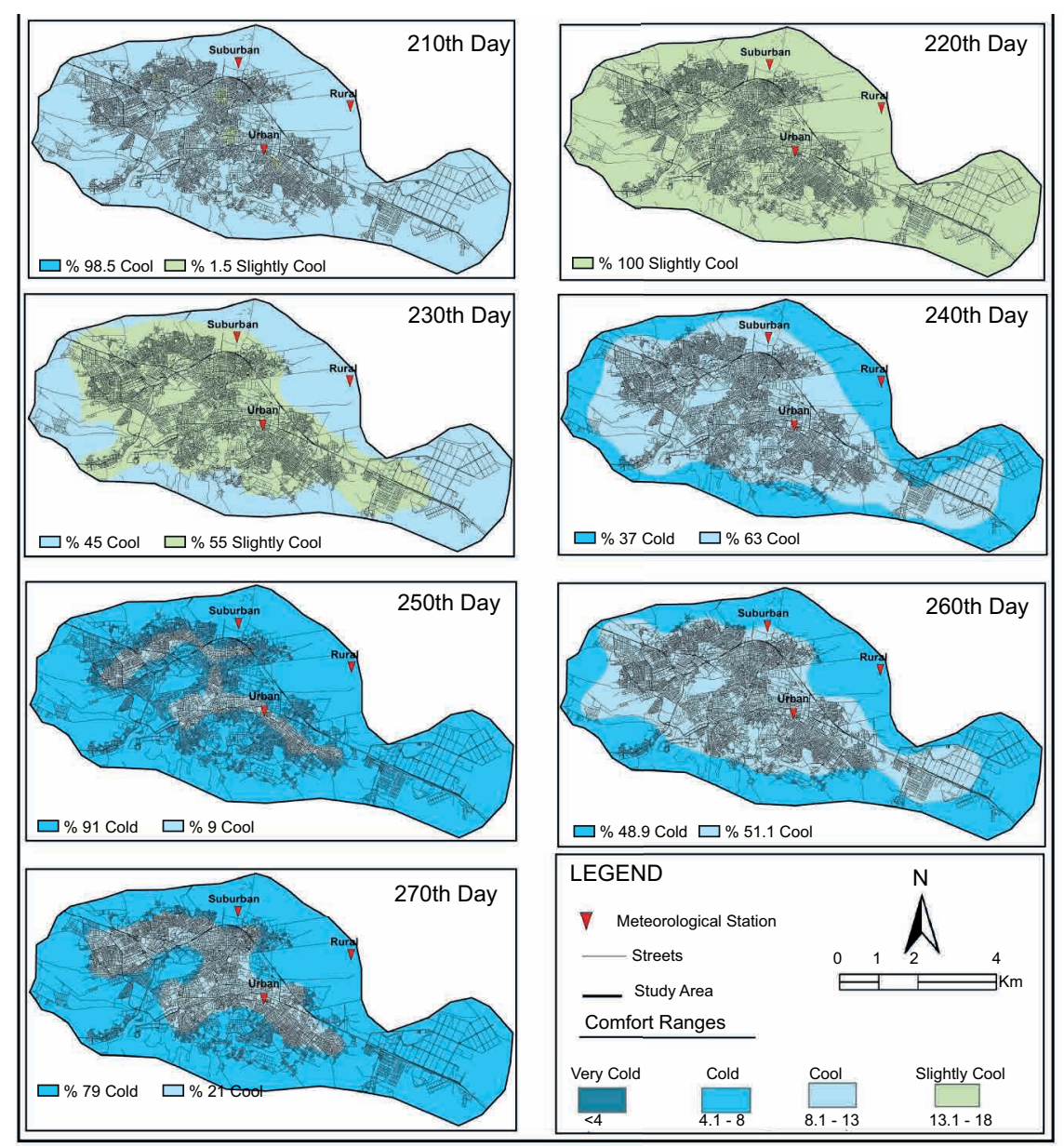

Fig. 9. Spatial distribution of daily average minimum PET values.

cold stress and $56.9 \%$ under cold stress. Very cold stress was observed in rural areas and cold stress was observed in urban and suburban areas. On day 150, cold stress was determined throughout the study area. On day 160, 20 and $80 \%$ of the study area experienced cold stress and cool, respectively, and on day $170,65.7 \%$ of the area (rural) was under the effect of cold and $34.3 \%$ (suburban and urban) experienced a cool range. On day 180, a cool range was observed in urban areas $(35.9 \%$ of the study area), and cold stress was felt in suburban and rural areas (64.1\%). From day 190 to 210 , the vast majority of the study area experienced cool and slightly cool ranges in dense building areas. On day 190, the slightly cool area corresponded to $1 \%$ of the study area, whilst this percentage was $1.3 \%$ on day 200 and $1.5 \%$ on day 210 . On day 220 , a slightly cool range was experienced in the study area. On day $230,55 \%$ of the study area (urban and suburban) faced a slightly cool range, while $45 \%$ (rural) experienced a cool range. On day $240,37 \%$ of the study area is under the effect of a cold range and $63 \%$ is under a cool range, while on day $250,91.0 \%$ of the area is under a cold range and $9.0 \%$ under a cool range. On day $260,48.9 \%$ of the area was under a cold stress and $51.1 \%$ faced a cool range, while on day $270,79 \%$ of the area was under a cold stress and in $21 \%$ the cool range was dominant. From day 240 to 270 , rural areas were under a cold stress. Suburban areas were under the effect of a cool range on day 240 and a cool range was observed on other days in urban areas.

Regarding the spatial distribution of mean PET values, the whole study area was under the same range on days 130,140 , and 150 (slightly cool), on days 210 and 220 (slightly warm), and on day 250 (comfortable). PET values were higher in urban 
areas on day 170 (comfortable), and days 180, 190 and 260 (slightly warm). As for urban and suburban areas, PET values were higher (comfortable) on days 160,250 , and 260 , as well as on days 200 and 230 (slightly warm) in urban and suburban areas. As for the distribution of the average daily maximum PET values, the whole study area was under the same range on days 130, 150 (slightly warm) and 160 (warm), from days 180 to 230 (hot), and on day 260 (very hot). Day 140 was slightly warm and on days 240,250 and 270 hot ranges were prevalent in urban areas, while on day 170 a warm range was prevalent in urban and suburban areas. Mean maximum daily PET values were prevalent in the area throughout the period showing warm ranges. With respect to the distribution of daily mean minimum PET values, on days 150 (cold) and 220 day (slightly cool), the whole study area was under the effect of the same PET range. On days 130, 250 days (cool) and 190, 200, 210 (slightly cool), urban areas showed the highest PET values in densely built areas with narrow streets. The lowest mean minimum PET values in urban areas were prevalent on days 180 and 270 (cool), 140 (cold), 160, 170, 240 and 260 (cool), and 230 (slightly cool) in urban and suburban areas.

\section{Discussion and conclusions}

Anthropogenic factors, mainly industrialization and concurrent urbanization cause cities to have unique climatic characteristics. In densely structured and industrial cities, both altered land use types and industrial and traffic combustion impact atmospheric features and thus climatic elements of the cities. Surface covers in urban areas, such as impervious surface of roads and roofs have different radiative, thermal and hydraulic properties than bare rock, soil, vegetation and water, their pre-existing counterparts; this causes urban environment to get warmer at a considerably higher rate by storing a larger amount of solar radiation and heat, and losing a smaller rate of energy.

From this point of view, every city should be analyzed on a micro scale basis and suggestions should be developed based on this type of evaluation. Turkey offers diversity in climatic characteristics even in short distances, mainly due to different topographic features. This study is significant in the literature since it deals with a middle size Turkish city, Eskişehir, in the Anatolia Region, where continental climatic features isolated from marine effects are prevalent. The city was industrialized and rapidly urbanized in the past, but over the last 2-3 decades industrial plants have been removed and some favorable urban development attempts have been made to increase the livability of the city center. The study conducted a detailed bioclimatic comfort analysis to determine the effect of a structured city center on thermal conditions by comparing it with suburban and rural counterparts. The results reveal that PET values in the city of Eskişehir are higher in urban areas than those determined in suburban and rural settings. Based on the mean PET values of 153 summer days, PET differences of $1.4,2.4 \mathrm{C}$ and $1.0^{\circ} \mathrm{C}$ were found between urban and suburban, urban and rural, and suburban and rural areas, respectively. As can be seen from the mean differences, urban areas still maintain its impact on thermal conditions, even though the city lost the majority of industrial facilities. This effect is directly related to the UHI effect, which includes the impact of surface characteristics, traffic load and other heat sources. The differences are within the ranges found in literature.

This study shows that the city center is warmer than its surroundings regarding hourly maximum and minimum PET values and also spatial distributions. The suburban area shows some advantages over urban and rural areas; however, it indicates a changing bioclimatic condition closer to that prevalent in suburban areas. This study also highlights how extreme conditions affect the spatial distribution of bioclimatic features, which give clues to decision makers on a spatial basis to deal with the negative impacts caused by unplanned spatial developments. From this point of view, the study clearly shows the UHI effect in urban areas over the whole period. Land-use change is seen to be especially impactful in the study area regarding the bioclimatic characteristics, in addition to traffic density and manufacturing activities. The city has experienced a planned physical development process over the last years in order to increase the vegetation cover and water surface by reorganizing a riverbank and designing green infrastructure. However, even under such conditions, in the torrid summer period these efforts do not seem to be efficient for obtaining comfortable conditions in the city center. 
More severe measures should be taken considering spatial planning and design principles to moderate the thermal effects during the summer and to increase the length of the comfortable period. Taking into account the prevalent wind direction to expand the cooling effect of water surface (already in use) to wider areas, restricting impervious surfaces, encouraging the use of public transport (already in use), and increasing the rate of green areas per capita, should be among the suggestions for the city center. The most important conclusion from the study may be that even if industrial structures have been removed from a city, it should have efficient urban systems ranging from green structures to water surfaces, public transport to motor-vehicle roads, to mitigate the effects of UHI-related human thermal discomfort.

\section{References}

Aboubakri O, Khanjani N, Jahani Y, Bakhtiari B. 2020. Thermal comfort and mortality in a dry region of Iran, Kerman; A 12-year time series analysis. Theoretical and Applied Climatology 139: 403-413. https://doi. org/10.1007/s00704-019-02977-8

Balık H, Yüksel ÜD. 2014. Integration of climate data to planning process. Turkish Journal of Scientific Reviews 7: 01-06.

Blazejczyk K, Kuchcik M, Dudek W, Krecisz B, Blazejczyk A, Milewski P, Szmyd J, Palczynski C. 2016. Urban heat island and bioclimatic comfort in Warsaw. In: Counteracting urban heat island effects in a global climate change scenario (Musco F., Ed.). Springer, Cham, 305-321.

Błażejczyk K, Baranowski J, Blazejczyk A. 2018. Climate related diseases. Current regional variability and projections to the year 2100. Quaestiones Geographicae 37: 23-36. https://doi.org/10.2478/quageo-2018-0003

Bruse M. 2004. ENVI-met. Available at: http://www. envimet.com (accessed on: March 7, 2021).

Çalışkan O, Türkoğlu N. 2014. The trends and effects of urbanization on thermal comfort conditions in Ankara. Journal of Geographical Sciences 12: 119-131.

Demircan N, Toy S. 2019. Checking three - year differences in some climatic elements between urban and rural areas after a twelve - year period considering some effective parameters and solutions. Fresenius Environmental Bulletin 28: 718-725.
Fukuoka Y. 1997. Biometeorological studies on urban climate. International Journal of Biometeorology 40: 54-57. https://doi.org/10.1007/BF02439412

Grimmond S. 2007. Urbanization and global environmental change: Local effects of urban warming. The Geographical Journal 173: 83-88. https://doi. org/10.1111/j.1475-4959.2007.232_3.x

Gulyás Á, Matzarakis A, Unger J. 2010. Comparison of the urban-rural comfort sensation in a city with warm continental climate. Proceedings of BIOMET $7473-479$.

Gümüş N. 2004. Urban development and urban typology in Eskişehir. I. International Symposium on Eskişehir Throughout History at Eskişehir-Türkiye: 153-164.

Höppe P. 1999. The physiological equivalent temperatureA universal index for the biometeorological assessment of the thermal environment. International Journal of Biometeorology 43: 71-75. https://doi.org/10.1007/ s004840050118

ISO. 2005. ISO 7730 2005. Ergonomics of the thermal environment. Analytical determination and interpretation of thermal comfort using calculation of the PMV and PPD indices and local thermal comfort criteria. Available at: https://www.iso.org/obp/ui/\#iso:std:iso:7730:ed-3:v1:en:sec:4 (accessed on February 26, 2021).

Kovacs A, Nemeth A. 2012. Tendencies and differences in human thermal comfort in distinct urban areas in Budapest, Hungary. Acta Climatologica et Chorologica Universitatis Szegediensis 4: 115-124.

Landsberg HE. 1981. The urban climate. 1st ed. International Geophysics Series, vol. 28. Academic Press, London, 275 pp.

Laschewski G, Jendritzky G. 2002. Effects of the thermal environment on human health: An investigation of 30 years of daily mortality data from SW Germany. Climate Research 21: 91-103. https//doi.org/10.3354/ cr021091

Matzarakis A, Mayer H. 1996. Another kind of environmental stress: Thermal stress. WHO Newsletters, 18: 7-10.

Matzarakis A, Mayer H, Iziomon MG. 1999. Applications of a Universal Thermal Index: Physiological Equivalent Temperature. International Journal of Biometeorology 43: 76-84. https://doi.org/10.1007/ s004840050119

Matzarakis A, Rutz F, Mayer H. 2007. Modelling radiation fluxes in simple and complex environments - 
Application of the RayMan model. International Journal of Biometeorology 51: 323-334. https://doi. org/10.1007/s00484-006-0061-8

Nastos TP, Matzarakis A. 2011. The effect of air temperature and human thermal indices on mortality in Athens, Greece. Theoretical and Applied Climatology 108: 591-599. https://doi.org/10.1007/s00704-0110555-0

Oke TR. 1973. City size and the urban heat island. Atmospheric Environment 7: 769-779. https://doi. org/10.1016/0004-6981(73)90140-6

Paramita B, Matzarakis A. 2019. Urban morphology aspects on microclimate in a hot and humid climate. Geographica Pannonica 23: 398-410. https://doi. org/10.5937/gp23-24260

Robaa SM. 2003. Urban-suburban/rural differences over Greater Cairo, Egypt. Atmósfera 16: 157-171.

Toy S. 2010. Evaluation of recreational areas in east Anatolia region for bioclimatic comfort values. Ph.D. thesis. Atatürk University, Turkey.

Toy S, Yilmaz S. 2009. Bioclimatic comfort in landscape design and its importance for living areas. Journal of the Faculty of Agriculture 40: 133-139. Available at: https://dergipark.org.tr/tr/pub/ataunizfd/ issue/2929/40540 (accessed on March 7, 2021).
Toy S, Y1lmaz S. 2010. Evaluation of urban-rural bioclimatic comfort differences over a ten-year period in the sample of Erzincan city reconstructed after a heavy earthquake. Atmósfera 23: 387-402.

Toy S, Aytaç AS, Kantor N. 2018. Human biometeorological analysis of the thermal conditions of hot Turkish city of Şanliurfa. Theoretical and Applied Climatology 131: 611-623. https://doi.org/10.1007/ s00704-016-1995-3

Toy S, Kayıp DB, Çağlak S. 2019. A (bio)climate sensitive urban design example in the city of Eskişehir. Gümüşhane University Journal of Science and Technology Institute 9: 353-361.

Unger J. 1999. Comparisons of urban and rural bioclimatological conditions in the case of a Central-European city. International Journal of Biometeorology 43: 139144. https://doi.org/10.1007/s004840050129

VDI. 1998. VDI 3787. Part I: Environmental Meteorology, Methods for The Human-Biometeorological Evaluation of Climate and Air Quality for The Urban and Regional Planning at Regional Level. Part I: Climate. Verein Deutscher Ingenieure/DIN-Handbuch Reinhaltung der Luft, Band 1b, Düsseldorf, 29 pp.

Y1lmaz E. 2013. Heat island in Ankara city. Ph.D. thesis. Ankara University, Turkey. 